\title{
Societies Need New Perspectives on Race and Ethnicity: Societies in Harmony (Religious Context)
}

\author{
İbrahim Kurt \\ Stichting Cosmicus, The Netherlands \\ Email: ibrahimkurt42@gmail.com
}

\begin{abstract}
After many centuries, humankinds have reached today's time by passing the centuries' gatherings to their offspring. The civilizations which were established in the different part of the world have had their own culture according to their needs, religions, daily routines etc. One more step from here to cultural and traditional attitudes which were risen and had been started to show them on individual's behaviors and ideas. During these periods, the individuals specifically have learned and understood life from their societies. So, individuals' behaviors and attitudes are shaped according to societies what cultural arguments they have. The perception and understanding of arguments can be different in those many centuries but there have-always- been race and ethnicity. The interpreting of the terms specifically has shown itself weakly or strongly from the deep sight of the history till now. This article has a general glance at race and ethnicity for seeking and finding the middle path in the societies. It is important to study on race and ethnicity and to build a new understanding and perspective for humans and how to bring positive ideas for societies and nations.
\end{abstract}

Keywords: Culture, Ethnicity, Ignorant Educated People, Race, Society

\begin{abstract}
Abstrak
Selama berabad-abad, umat manusia telah mewariskan kepada keturunan mereka. Peradaban yang terbentuk di berbagai belahan dunia memiliki budayanya masing-masing sesuai dengan kebutuhan, agama, rutinitas seharihari dan lain-lain. Langkah lain dari sini menuju budaya dan budaya tradisional yang telah tumbuh dan mulai menunjukkannya pada perilaku dan gagasan individu. Selama periode ini, individu secara khusus telah belajar dan memahami kehidupan dari komunitasnya. Dengan demikian, perilaku dan sikap individu dibentuk menurut argumen budaya yang mereka miliki. Persepsi
\end{abstract}


dan pemahaman argumen dapat bervariasi selama berabad-abad tetapi selalu ada ras dan etnis. Menafsirkan istilah secara spesifik telah menunjukkan dirinya lemah atau kuat dari sudut pandang historis yang dalam hingga saat ini. Artikel ini memiliki pandangan umum tentang ras dan etnis untuk menemukan dan menemukan jalan tengah dalam masyarakat. Penting untuk belajar tentang ras dan etnis serta membangun pemahaman dan perspektif baru bagi umat manusia dan bagaimana membawa ide-ide positif kepada masyarakat dan negara.

Kata Kunci: Budaya, Suku, Orang Berpendidikan yang Jahil, Ras, Masyarakat

\section{Introduction}

The history of human beings has got a long journey to this century. Like a rolling snowball, it has collected and contains many thing(s) for the human nation. In these situations, human beings have also created artificial clusters in relations. The common connection on behavior, experiment, goal and believes and about societies and their individuals would take which thing(s) is (are) valuable around values and how they would live and relate in the specific society (Huitt, 2004). In social life, the relations are generally based on people's lifestyles and understanding the way of life according to cultural practices. During improving one's social and physical environment according to relations in the society, people's behaviors, attitudes and the aims, targets of members of the society are shaped by the values (Magsino, 1979). These relations are commonly based on age, class, gender, race and ethnicity. Race and ethnicity are important in society and therefore the mindset and perception of people work generally on those issues.

The idea on race and ethnicity comes from their history and in some societies, this has caused problems among people and nations. The different understanding of relations and values can have negativity among the people and groups according to their behaviors and attitudes in the society (Yiğittir and Öcal, 2011). Nowadays racism and ethnicity may be underlined by a strong attachment in those relations and opposite sides, groups etc. against to these behaviors come up the surface of the society. During living together and in a harmony in multicultural societies can become risky situations with various troubles by underlining and emphasizing different values and lifestyles (Ryan and Bohlin, 1999).

After having a common idea on basic relation problems on separation ethnocentrism, deviance and discrimination communities; societies are separated into groups or parts with ideology of racism 
and ethnocentrism. Nevertheless, emphasizing the big spots on race and ethnicity among societies or people gives negative impact on relations, perceptions and psychology of the communities and societies. So, there is a negative understanding and perception on race and ethnicity among human beings. It can easily damage the coexistence of the societies. Losing the unity and solidarity would make hard to cope and deal with the encountered social problems. The common values which share in the societies cherish the unity and solidarity which set the peaceful environment with togetherness (Kurt, 2104). Values are getting more important to keep alive for building the social life among members with their lives in attitudes and behaviors to gain them.

The article is structured as follows. In the race and ethnicity part, it is pointed that the explanations of these two terms with biologically superficial physical view and differences in a specific society and how the social groups or classification can be seen according to the different races.

In the discussion part, it is mentioned the position of discrimination, poverty, and education. People who belong to different ethnic groups or have differences in race may be in the same society or in other societies. Education and common sense are so necessary with the participating expectable and proper attitudes and behaviors in the societies.

In the last part, it is focused with a general view to underline on the impact of positive perspective of race and ethnicity. Common values, shared ideas and feelings would make this world a better place. The differences without violence and discrimination make a harmony with tolerance and dialogue and bind the people and communities together, encourage the spirit of friendship and brother hood among people to make this world free from racism and ethnicity problems.

This article, it is aimed to get a large point of views about how the individuals and societies can respond and find new solutions to those challenges to make good relations with other people in the society. The negative understanding and acting on the terms of race and ethnicity can be rethink, reshared and understand with all aspects. It can be understood that world is beautiful and interesting with "other" people and their ideas. These make the world a living place for all people. 
Literature research method is used to identify the terms and understanding of the relations in the societies. Race and ethnicity were described with its reflections to societies life and the relations among the individuals will be discussed from the perspective of values.

\section{Results and Discussion}

The research question is: 'How can individuals and people make positive relations even though they have different backgrounds, race and ethnicity in the same society? What is the relation between people's race and ethnicity in their affective relation with the values in the society?

The concepts subject to the research will be explained sequentially. While the concepts will be explained in the order of race ethnicity and values, the result and suggestion's part will be evaluated from the point of shared values. Because human beings are social creatures, they formed societies by coming together with other people. By coming together, sharing the same space and culture, interacting with, by regulating the social life, the human beings form the society (Dictionaries, 2014).

\section{Race and Ethnicity}

Race and racism appear to be similar, but they are not, there is a definite difference between the two. Both race and racism can be seen in almost all the societies. Race is a way of differentiating among humankind based on the biological differences. Race is defined based on common physical characteristics, people with their differences and similarities distinguished from others in societies (Marger, 2003; Myers, 2007; Boundless, 2017). The differences and similarities such as bone structure and skin, hair, or eye color are the main identification for race. So, when people talk about biologically superficial physical view and differences in a specific society, the social groups or classification can be seen according to the different races.

Race has been used as a way of giving an individual his or her group identity in a multiethnic, multi-cultural society (Banton, 2015). Race is biologically inherited. In deciding race people have considered biological factors, skin, and hair or eye color. This means all people 
belong to a particular race based on these factors. However, it is impossible for one to change his or her race.

Since race is one of the major signals in differentiating among individuals, in some societies, this has become a tool of discrimination as well. Classifying or comparing another race (its differences and similarities) solely by the physical view of other people and having perception on those characteristic features may cause certain bounders and barriers in the mindset (Tannen et al. 2015). Then, the word racism comes up to inside of relations and societies, may be with its prejudice and bias. Racism is a way of treating each other based on race. Race - mainly people- has made a lot of different social groups all over the world and because of that it is seen racism among these groups (Wodak and Reisigl, 2015). Both exist in social constructions and attitudes of people decide the influence of these on the total population of a society. Some people ill-treat other groups of people based on their race. Some societies form their own ideologies believing that their race is the most superior and see others as inferior (Andreouli, et al. 2015).

Racism is a kind of feeling that is associated with prejudice and superiority over one's own race. Racism is seen in certain social actions, beliefs, political behaviors and in social relationships (Wodak and Reisigl, 2015; Grosfoguel, 2016). People who belong to a particular race may intend to think that their race is more superior to all the other races and based on this they look down upon other racial groups. Those who uphold the belief that their racial identity is better are known as racists (Bassett et al. 2017). Due to these racial ideologies, there can be sufferings for the under privileged racial groups. Racial discrimination is led by the racist mindset and the most powerful groups oppress the dominated groups and there can be racial discrimination toward the disadvantaged group. This may sometimes include slavery and genocide where people suffer a lot due to their race.

Ethnicity mostly talks about where you are form. It suggests the tradition and customs that belong to the region one is from. Ethnicity is state of belonging to describe the cultural identity of a person or a social group with the shared cultural practices and lifestyles, perspectives, and geographic regions that set apart one from other or one group of people from another (Myers, 2007; Banks\&Banks, 1995; Schweder et al., 1998). Distinguishing with various characteristics like ancestry, a sense of history, nationality language, religion, dress, and 
customs are used to identify their identities. Race is based on the biological differences whereas ethnicity is based on the cultural.

One difference between race and ethnicity is that race is unitary. It is important to understand that a person can belong to one race only. Although he belongs to just one race, he can still have multiple ethnic connections. One can call a person African, but if you want to call him in terms of race then you call him either black or white. Thus, race is socially imposed whereas ethnicity is not socially imposed. A race is a biologically subspecies whereas ethnicity does not refer to any species (Myers, 2007). Thus, one can change one's ethnicity but not race.

As race and ethnicity have been a problem creating factor in the past and remains so today, it is necessary to differentiate race and ethnicity. Race is the major divisions of humankind having distinct physical characteristics whereas ethnicity is belonging to a social group that has a common national or cultural tradition and customs. Race and ethnicity are two words that appear to be similar but have some difference. Race may be taken to mean a major division of humankind. Race would give rise to distinct physical characteristics. Ethnicity does not indicate a person's race. Ethnicity is all about traditions and customs.

Ethnicity and racism may lead to discrimination among individuals in a society. People can be treated unfairly because of skin color or just belonging to a certain ethnic group. Race and ethnic discrimination can be direct or indirect and can also take the form of harassment or victimization.

With direct race and ethnic discrimination, some people can be treated less favorably than others in the same circumstance whereas in indirect race and ethnic discrimination, rules and policies or practices of people of a particular racial, ethnic or nation are less likely to be able to meet than other people, and this places them at a disadvantage. These forms of discriminations make individuals feel rejected and can lead to sadness, depression and a feeling of emptiness or guilt. They slow productivity, development and can lead to conflicts and social disorders.

Poverty can be also fueled by racism and ethnicity. For instance, sometimes societies are divided into groups because of race. When people are divided it becomes difficult for them to work together or plan on activities that can improve their lives financially and economically. This slows development and makes it difficult for others 
to access some social services. Crime rate rises in societies where most of the people are poor.

When the ignorant educated individuals continue to use education as a weapon for distinguishing them as superiors, people in societies tend to segregate each other and these behaviors can influence crime.

Race and ethnicity may lead to hatred and favoritism. People who belong to different ethnic groups or have differences in race may detest each other or being cared for or being allocated responsibilities than others. If this is encouraged, leads to physical abuse or violence. Favoritism normally disunites people in societies. If people are disunited their participation in developmental activities tends to be low and care less for issues that affect them at community level. Enmity is encouraged and this leads to bitterness and deep hatred.

\section{Conclusion}

Humans need to treat each other with mercy and ensure that peace is encouraged in societies to solve the problems of racism and ethnicity. If people come up with common values so that each member knows what to expect of each other or have some shared principles by which to resolve differences without resolving to violence, this world would be a better place, racism and ethnicity wouldn't exist among human beings. Societies should have values that binds them together, encourage the spirit of friendship and brother hood among people to make this world free from racism and ethnicity.

Tolerance and dialogue can also help in solving the problems that arise due to racism and ethnicity. Societies need to have peaceful exchange of ideas for them to come up with positive solutions that can resolve differences without violence. Tolerance safeguards against persecutions and evils that are necessarily associated with ethnicity and racism. Hate and curse should be discouraged and peace and harmony among people in societies be encouraged.

Power hungry people should not be made leaders as they sometimes make decisions that negatively impact others in societies thereby encouraging racism and ethnicity. Rather people who are relatively grounded, reasonably self-aware and do not take things or themselves too seriously or don't change in a bad way are the ones with the best chance of leading successfully. Power hungry people get 
carried away with their desires and do not consider other people's views. They do not like to be criticized and are of the perception that they are always right. This cause disunion among people and encourages greediness. Greedy people destroy societies.

Recognizing human dignity in people plays a very big role in curbing racism and ethnicity. This makes people to respect and honor each other's values. Respect for human rights can help people to understand each other in societies. Human rights bring people together because they are inherent to human beings of all nationalities, sex, ethnic groups, and races. These human rights are interrelated, interdependent and indivisible.

People should also be sensitized on racism and ethnicity and encourage victims to be reporting issues of racism to authorities or to speak up. If people in societies are aware of how to deal with racism, they stand a better chance in addressing the issues when encountered. A bad expected behavior cannot be changed or fixed by hating or announcing it an enemy. Hate bears hate. Moving from on this path the damages of racism and ethnocentrism ca be more and more by having a distance and calling "the others". Because the racist and ethnocentrist also call "the others". Instead of having a distance, need to build bridges to avoid the disunity and prevent the problems which can be caused among the relations.

When people live in harmony, recognize the contributions that each person make to societies, appreciate each other's contributions towards issues that affect societies and recognize that we are all on this planet together and that we stand to gain more when we work together rather than against each other. Racism and ethnicity can be avoided if love for humanity is practiced. Societies would be united regardless of race end ethnic groups and wars and conflicts would be avoided. We should all try to follow the golden rule that encourage us to do onto others as we would want them to do onto us as the saying goes "if you live in glass house, do not throw stones at others".

\section{REFERENCES}

Andreouli, E., Greenland, K., Howarth, C. 2015. 'I Don't Think Racism Is That Bad Any More': Exploring the 'End of Racism' Discourse among Students in English Schools. European Journal of Social Psychology, Retrieved 23rd Dec. 2018 from https://doi.org/10.1002/ejsp.2143. 
Banks, J., Banks, C. 1995. Handbook of Research on Multi-Cultural Education. New York: Macmillan Publishing.

Banton, M. 2015. Racism. Wiley Online Library, John Wiley \& Sons, Ltd. Retrieved 5th December 2018 from https://doi.org/10.1002/9781118663202.wberen539.

Boundless. 2018. "Culture, Ethnicity, and Race." Boundless Communications. Retrieved 13th June 2018 from https://www.boundless.com/communications/textbooks/boun dless-communications-textbook/analyzing-the-audience7/demographic-factors-to-consider-38/culture-ethnicity-andrace-169-8389/

Bassett, M. T., Krieger, N., Bailey, Z. 2017. Charlottesville: Blatant Racism, Not Grievances, On Display. The Lancet, Volume 390, Issue 10109, P2243, November 18, 2017, Retrieved 13th January 2019 from DOI: https://doi.org/10.1016/So140-6736(17)32855-6

Dictionary, Law, http://thelawdictionary.org/society/ erişim:14.10.2019

Grosfoguel, R. 2016. What is Racism? Journal Of World-Systems Research, University of Pittsburgh Press. ISSN: 1076-156X | Vol. 22 Issue 1 Page 9-15 http://dx.doi.org/10.5195/jwsr.2016.6o9 | jwsr.org

Huitt, W. 2004. Values, Educational psychology interactive, Valdosta, GA: Valdosta State

University,

http://www.edpsycinteractive.org/topics/affect/values.html Access date:

22.09.19

Kurt, I. 2014. Social Life and Values Education from the View of AKHI Association. Mevlana International Journal of Moral and Values Education (MIJMVE) Vol. 1(1), pp. 39-45

Magsino, R. F. 1979. What moral education in newfoundland schools?. Society and

Education in Newfoundland, (II), 339-344.

Marger, M. 2003. Race and Ethnic Relations: American and Global Perspectives. Belmont, CA: Wadsworth.

Myers, J. P. 2007. Dominant-Minority Relations in America. Boston: Pearson. 
Ryan, K. \& Bohlin, K. 1999. Building character in schools, San Francisco, Jossey-Bass Pub

Schweder, R., Goodnow, J., Hatano, G., LeVine, R., Markus, H., Miller, P., Damon, W., Lerner, R. M. 1998. The Cultural Psychology of Development: One Mind, Many Mentalities. Handbook of Child Psychology: Vol. 1. Theoretical models of human development (5th Ed.) New York: John Wiley \& Sons.

Tannen, D., Hamilton, H. E., Schiffrin, D., Editor(s). 2015. The Handbook of Discourse Analysis, 2; ISBN:9780470670743 |Online ISBN:9781118584194 |DOI:10.1002/9781118584194, Copyright ( $(2015$ John Wiley \& Sons, Inc.

Wodak, R., Reisigl, M. 2015. Discourse and Racism Chapter 27: The Handbook of Discourse Analysis, 2; Editor(s): Tannen, D., Hamilton, H. E., Schiffrin, D., ISBN:9780470670743 |Online ISBN:9781118584194 |DOI:10.1002/9781118584194, Copyright (C) 2015 John Wiley \& Sons, Inc.

Yiğittir S. \& Öcal A. 2011. High school history teachers' views on value and value of Education, KMU Journal of Social and Economic Research, 13(20), 117-124. 